\title{
China drive toward Africa between arguments of neo-colonialism and mutual-beneficial relationship: Egypt as a case study
}

China drive toward Africa Egypt as case study

Alyaa Wagdy el-Shafei

Department of Knowledge Support and Translation, General Authority for Investment and Free Zones, Cairo, Egypt, and Mohamed Metawe

Department of Political Science, Faculty of Economics and Political Science, Cairo University, Giza, Egypt

\begin{abstract}
Purpose - The main purpose of the paper is to examine the truth behind allegations of neo-colonialism performed by China toward Africa, which was raised due to the growing relationship between China and Africa that enhanced the debate between supporters of the notion of neo-colonialism or mutual beneficial relationship. In addition to the growing number of arguments are on the dominance of PRC in Africa over the western powers as European Union or United States in the Continent.

Design/methodology/approach - The paper investigates the claims of neo-colonialism practiced by China toward Africa through the lenses of international political economy using the Interdependence theory of neoliberalists. Egypt was selected as a case study due to the emphases that Egypt gives to China as a strategic partner and as rising economic power as well as representing a way of diversifying Egypt's foreign policy and an additional economic partner beside the western ones. The research relied on two interwoven indicators to investigate the main argument: Trade and Development Aid.

Findings - The two pillars of analysis indicate that the growing relationship between Egypt and China is a form of interdependent relationship that is expected to get further complex in the future, which is relatively indicated among other things in the synergy Egypt has made between its Vision 2030 and China's Belt and Road Initiative. In reference to development aid, China uses different techniques that is not commonly used by the donors of Official Development Assistance ("ODA"), and due to unpublished actual data on China's aid figures, any indication of dominance is hard to attain regardless a solo incident of debt trap in Africa, the model of China's aid is provided through low-interest loans for development projects that is highly important for developing countries.

Originality/value - The paper tried to engage in the ongoing debate and examine the truth behind the neocolonial allegations from the perspective of international political economy, which is an added value to the literature in this regard as the data provided are prepared for the present research purpose.
\end{abstract}

Keywords Neo-colonialism, International political economy, Egypt, Africa, China

Paper type Research paper

\section{Introduction}

Occupied by the search for new markets and cheap raw materials, emerging international actors such as the People's Republic of China, India or Brazil have tried to compete over Africa. Nevertheless, China economic power was obviously more substantial than other emerging

(C) Alyaa Wagdy el-Shafei and Mohamed Metawe. Published in Review of Economics and Political Science. Published by Emerald Publishing Limited. This article is published under the Creative Commons Attribution (CC BY 4.0) licence. Anyone may reproduce, distribute, translate and create derivative works of this article (for both commercial and non-commercial purposes), subject to full attribution to the original publication and authors. The full terms of this licence maybe seen at http:// creativecommons.org/licences/by/4.0/legalcode

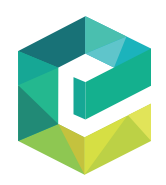


REPS

7,2

138

countries (Grimm and Hackenesch, 2017). The Chinese rapid increasing involvement in Africa has awaken the allegations of neocolonialism and drawn a significant attention from European states who accuse China with allegations of performing neo-colonial practices. There are four pieces of evidence support this argument. The first piece of evidence is the fact that the Chinese are using the same tactic of the colonial powers, which is extracting raw materials from the African soil in exchange for cheap prices. The second is the debts that China use as a tool for domination to this relatively new market. Such skeptical view toward Sino-African relations can be traced back to the endorsement of "Going Out" strategy at the beginning of 2000s (Sun, 2014), i.e. the Chinese government encourages corporations to invest overseas, and the following series of visits conducted by the Chinese president Hu Jintao to African states providing loans without political conditions that were interpreted as encouraging corruption and supporting rogue states (The Guardian, 2007). Such allegations were claimed by many prominent figures including senior politicians such as Britain's former foreign secretary Jack Straw "Most of what China has been doing in Africa today is what we did in Africa 150 years ago." (Stevenson, 2006).

Interestingly to know that during the sixties, a series of conferences held in Accra 1959, Tunisia 1960 and in Cairo 1961 consecutively under the name of "All Africa People's Conference[s]" ("AAPC") and were occupied among other things with the fear of fallen under neocolonial practices performed by western imperial powers. Such conferences were then supported by China among other eastern socialist Allies. The third conference held in Cairo 1961 provided the first official recognition on neo-colonialism in its resolution describing it as a status where "The survival of the colonial system in spite of formal recognition of political independence in emerging countries, which become victims of an indirect and subtle form of domination by political, economic, social, military, or technical means” (Martin, 1985, p. 191).

The third piece of evidence claims that despite the fact China is technically not occupying any African country, the growing large number of Chinese workers in the continent which in some countries caused the discontent of the African workers, such as those workers in Kenya who protested against the work conditions, wages and the large number of Chinese labor during the implementation of the USD13.8 billion rail project which linked Kenya's Indian Ocean port of Mombasa to the capital Nairobi, then on to Uganda, which is part of a package of deals signed between Kenya and China in 2013 (Akwiri, 2015), sometimes is used as an evidence held against Chinese allegedly hidden intentions toward Africa. The fourth piece of evidence is the Chinese policy of ignoring imposing conditions before providing any assistance to African countries facing accusations of oppression and neglecting human rights (Zweig and Jianhai, 2005).

Against this backdrop, another argument was presented indicating that China is not performing any neo-colonial practices toward countries in Africa. This was clearly illustrated by the Chinese Prime Minister Wen Jiabao when he said "The hat of 'neo-colonialism' simply does not fit China" during a press conference in Cairo (Chinese Premier Wen Jiabao, 2006). In order to support this point of view, Chinese officials adopted a rhetoric that defends its intentions toward Africa embracing the de-colonization movements that blossomed in Africa after Second World War as well as emphasizing its stand in supporting reciprocal benefits between China and African countries. In 2015, Wang Yi, China's Foreign Minister, during his tour in Kenya said that China will not follow the steps of former western colonists and "will not sacrifice Africa's ecological environment and long-term interests" (Harvard Political Review, 2017). There are two main pieces of evidence support this argument, the first one refers to the fact that the Chinese expansion is part of China's outward role in pursuing capitalism-policies (Taylor, 2006, pp. 937-959), i.e. China is adhering to the market economies through concluding contracts with governments in Africa that rely on demand and supply, generating revenues and searching for energy sources to support the growing internal economic expansion as well. The second piece of evidence refers to the fact that the Chinese 
multi-dimensional interactions with African countries is part of the modern interdependence relationships among world countries. The Silk Road, which China is working on that links Africa, Asia and Europe into one circle of cooperation proves that it is a mutual-beneficiary relationship.

Africa is a continent that enjoys huge untapped reserves of natural resources and represents a growing large market that place the continent in the core interest of world countries, therefore anticipating the plans and road map of international principal actors from an academic perspective would assist in figuring out the best way to take advantage of these plans domestically and put the continent in general and Egypt in particular on the right sustainable development path.

\section{Research question}

RQ1. Why do some scholars argue that China's drive toward Africa is a form of neocolonialism, while others perceive it as a mutual beneficial relation?

\section{Research sub-questions}

(1) What are the theories that explain the Chinese drive toward Africa?

(2) What are the pieces of evidence of those who argue that China is performing a neocolonial practices and evidences of their opponents?

\section{Theoretical perspective}

Unlike the ascending of hegemonic powers along the history, China as a rising power shall be considered the only power that did not build its own state through a direct military invasion or colonization, rather it executes and promotes the peaceful rise model that is driven by capital, resource acquisition and technology (Msimango, 2016). Therefore, theorizing its gradual rise and its relationships with African countries shall be made depending on modern theories that allow the analysis of such novel peaceful rise and the modern Sino-African relations from the field of international political economy. The research in hand will depend on a neoliberal theory in order to analyze through its lens the arguments under investigation and investigate an interdependent relationship between Egypt and China.

\section{Interdependence theory}

Due to many changes in international arena upon the end of Cold War stimulating new readings to the new growing pattern of international relations that concentrated more on economic and technological advances and communications, the theory of interdependence was able to cope with these changes and provide relatively accurate analysis, while attaining to the concept of power as a fundamental concept and extending it as well. Therefore, the theory of interdependence from the international political economy scope is applicable to study China as an active peaceful actor in the African continent.

Interdependence theory was developed by Robert O. Keohane and Joseph S. Nye in their classic book within international relations theory entitled: "Power and Interdependence" in 1989. It provided an adequate understanding to the international changes, the roles of emerging powers, a profound analysis to the relatively decline of military power and the increasing international economic interdependence. The theory explains interdependence in politics as "situations characterized by reciprocal effects among countries or among actors in different countries. These effects often result from international transactions - flows of money, goods, people, and messages across international boundaries" (Keohane and Nye, 2012). 
REPS

7,2

Interdependence occurs when reciprocity achieved, where the relationship among involved actors has the shape of asymmetry in dependence and not necessarily represent an evenly balanced mutual dependence.

The theory extended the role of power of international actors, including states, by encompassing two main dimensions, which are sensitivity and vulnerability. Sensitivity concept is relevant to the impact on each actor/country involved in an interdependent relationship as a reflection of imposed changes from outside, for instance the international financial crisis. While vulnerability explains whether a country has the ability to execute alternative policies that limit transaction costs imposed by external effects of economic policies resulting from outside such as boycotts or other trade disruptions (del Rosío BarajasEscamilla et al., 2016).

Interdependence as a concept was elaborated by Keohane and Nye to respond to real-life situations, which resembles in most cases the notion of complex interdependence. Complex interdependence is defined through abstracting reality into the most ideal three conditions which are the absence of force, the lack of hierarchy among issues and the presence of proliferation of channels of contact between societies. It is conceived that the actual situation would approximate these ideal conditions to a certain degree. The first condition of force absence entails that control is more accurately be measured through the ability of governments to control the outcomes and ability to adapt to change with minimum costs rather than its military power. The second condition on the difficulty to arrange goals and hierarchy of issues is manifested in that the governments are now responsible for the economic prosperity beside the military security due to the long-evolvement of development of the welfare state. The third condition of the various channels of communication is achieved due to the incredible technological advances and transportation that minimizes distance barriers.

In reference to the three mentioned conditions, Keohane and Nye (2012, p. 194) elaborated that the notion of states' welfare evolved over time and got more complicated by eliminating the military power as a state priority and equal gains as an indication of reciprocity hence denying neo-colonial practices. Such complication resulted in a pattern of coexistence between international actors and a fluctuation in priorities.

The interdependence theory fits in the analysis of the relationship between Egypt and China. As the military power plays a negligible role in this relationship and the diminished military power between Egypt and China is maintained due to the mutual respect and noninterference agreed upon between both countries.

Moreover, China has plenty of issues on the agenda with Egypt that exceeds the economic relations, where Egypt relations with China are strong on multiple levels of contacts. Trade volume with China is on a constant prominent increase over the years. In addition to the comprehensive strategic agreements that Egypt maintain with China, the relations are strong on the official levels as the notable increasing official conversions with China expressed in the official visits between the two countries and mutual consent on global matters. Being partners, although issues on Egypt-China agenda are more hierarchal and limited in number, but they are on the rise especially after China's BRI. Because it is almost impossible to mapping all aspects of the relationship between both actors, more light will be shed on the applicability of interdependence theory to the most prominent features of the relationship in Chapters One and Two.

\section{Glimpses on China-Africa relationships with regard to the arguments of the study}

China has built many projects in Africa, including but not limited to, roads, railways, bridges, dams, and economic zones as a way through which it could penetrate Africa growing markets 
and wide energy and other resources, as well as to reinforce strong cultural and diplomatic relations. Such cooperation is pro to the mutual-beneficial aspect of the argument (Dynamic, 2019). On the other side, the sustainability of BRI financing, as an example, has enhanced the interrogatives of Chinese neo-colonial practices in Africa, as the sustainability of loans provided to African countries will depend in part on the productivity of the BRI projects themselves. However, the opacity of Chinese policy on its loan disbursements is of concern (Taylor and Zajontz, 2020).

\section{China relationship with Egypt (from 2007 till 2017)}

China scramble into Africa to fuel its economic growth by making use of raw materials in the continent and to gain a remarkable share in the African consumer markets has reflected the domestic imperatives of its Going Out strategy started in the nineties. In 1993, China became a net importer of oil, and in 2003, overtook Japan to become the world's second consumer of oil behind United States (Lanteigne, 2009). Such appetite would require, beside new unsaturated markets to its finished products, tightening its economic relations with African resource-rich countries as instruments of energy supplies as well countries on the road of international trade such as UAE.

Relations between China and African countries went relatively through three phases: the period from 1950s to 1970s, the main focus was on political development by adopting open-up and internal reform policies as well emphasizing shared values on anticolonial practices and support of national liberation movements occurring in Africa that started in the sixties; from 1980s till the Cold War, China relied on cooperation that is anchored on principles of equality and reciprocal benefit; upon the end of Cold War, China followed government-sponsored projects to acquire ground in markets and achieving common prosperity in economic side (Gadallah, 2016).

China's increasing economic relations with African counterparts have been backed largely by the Chinese government through its state-owned corporations or in part by its private companies. Such economic relations were highlighted through its Forum on AfricaChina Cooperation in 2006. Following the pattern of the present research, the following subsection will provide a thorough analysis of prominent engagement in Trade and Development Aid between China and Egypt.

\section{Trade relations between China and Egypt}

Egypt was the first African country to recognize the People's Republic of China in 1956. Before that in 1953 trade was already ongoing between the two countries and accounted at US\$11 million; US\$10 million for the exports to China and US\$600000 for imports from it (Hatab et al., 2012). Months before Egypt's recognition of PRC, the later had opened its commercial counsellor's office in Cairo early in 1956 (Cooperation between Egypt and China in Brief, 2004). A technical and cooperation agreement was signed in 1964 between China and Egypt; in the agreement China will provide industrial equipment and machinery worth US\$80 million and repayment will be spread over ten years starting 1972 with no interest rate; such generosity was not the norm from the Chinese side, therefore critics were likely to interpret such promise within the context of Sino-Soviet competition (Ogunsanwo, 1974). In 1985 a new trade agreement was signed stating that all bilateral trade would be settled with convertible foreign exchange from then on because all the transactions had been settled under clearing agreement for nearly 30 years before this agreement (Cooperation between Egypt and China in Brief, 2004).

In 1995, the two countries signed an economic and trade agreement to replace the 1985 trade agreement that emphasized the development of bilateral trade between the two countries. In August 1997, Egypt and China signed an avoidance of dual taxation and tax
China drive toward Africa Egypt as case study 
REPS

7,2

evading agreement, followed by signing letter of intent on mutual-beneficial economic and technical cooperation to encourage Chinese enterprises to establish joint ventures in Egypt. In 1999, Egypt was among countries that sign strategic cooperation agreement with China that covered political, economic, parliament and cultural aspects (Gadallah, 2016). By strategic it means, as defined by the Chinese Premier, Wen Jiabao in the ninth China-EU Summit in Finland, cooperation should be long term and stable (Zongze, 2008).

In November 2006, the two countries signed a memorandum of understanding and agreed to enhance all-round cooperation in trade, investment in an effort to elevate bilateral economic ties (Hatab et al., 2012). In 2009, Egypt was able to host the China-Africa Cooperation Forum signaling a new phase in their economic relation in order to enhance the strategic partnership and sustainable development between the two countries. Such cooperation was resumed even after Egypt uprising of 2011 and the political unrest that marred the political scene at the time, as early indications reflected that Egypt will continue to approach China and to diversify the foreign relations portfolio and considers it as a cornerstone to engage in Asia. Such engagement was mutual as Egypt represented China's third-largest trading partner in Africa in 2011 and considered Egypt as a gateway to the new markets of Africa and the Middle East (Zambelis, 2013). The Sino-Egyptian engagement was resumed following Muslim Brotherhood Party took power in Egypt, even a visit to Beijing was paid as the first official visit by president Morsi in August 2012. In 2013, the two countries maintained close political contact and Egypt relations with China was not affected after ousting Egypt's president, Mohamed Mursi, in 2013 after mass protests. Sound progress in 2013 has occurred on different levels as the bilateral trade volume grew as well as in terms of energy cooperation, where Sinopec International Petroleum Exploration and Production Corporation, a wholly-owned subsidiary of Sinopec, purchased some of the stakes of the assets owned by Apache Corporation of the US in Egypt.

A step forward indicating solid record of mutual cooperation was accomplished in 2014 during a presidential visit to China, the Egyptian president signed a comprehensive strategic partnership with the Chinese counterpart to cover all dimensions of economic cooperation including trade and investment and multiple levels of interactions encompassing people-topeople exchanges, in this partnership One China policy was mentioned, which is not a frequent case in most signed CSPs (Zhongping and Jing, 2014). Interesting to know that partnerships signed between China and world countries do not follow same mechanisms or one identified institutional framework, for example the CSP signed with EU includes dialogue over human rights issues while this was not the case in CSPs with developing world (Zhongping and Jing, 2014). Strategic partnership that is used by the Chinese government is used as an institutionalized diplomatic instrument that serves China's peaceful rise in the global unipolar system. Since 2014, until the current being China has signed four strategic partnerships in North Africa; Morocco, Sudan, Algeria and Egypt, the latter two being at comprehensive level. The Egyptian government officially launched the sustainable development strategy "Egypt Vision 2030" in February 2016 and incorporated more than 70 projects in the vision. Chinese leaders have pointed out on several occasions to fully synergize the development strategy of China "BRI" and that of Egypt "Vision 2030": the building of infrastructure and cooperation on capacity to make Egypt a supporting country along the "BRI" (Chen, 2018). China has listed Egypt as one of the top five destinations for mergers and acquisition activity under the BRI initiative.

The below figure presents the ratio of trade-to-GDP in Egypt's economy.

In Figure 1, the ratio reflects trade interdependence between Egypt and China and indicates advance in technological issues, transportation and above all massive increase in communication. It is worth noting that China's external trade-to-GDP-ratio is 60\%, which encourages other developing countries willing to prosper to increase such ratio (Tan et al., 2015). 


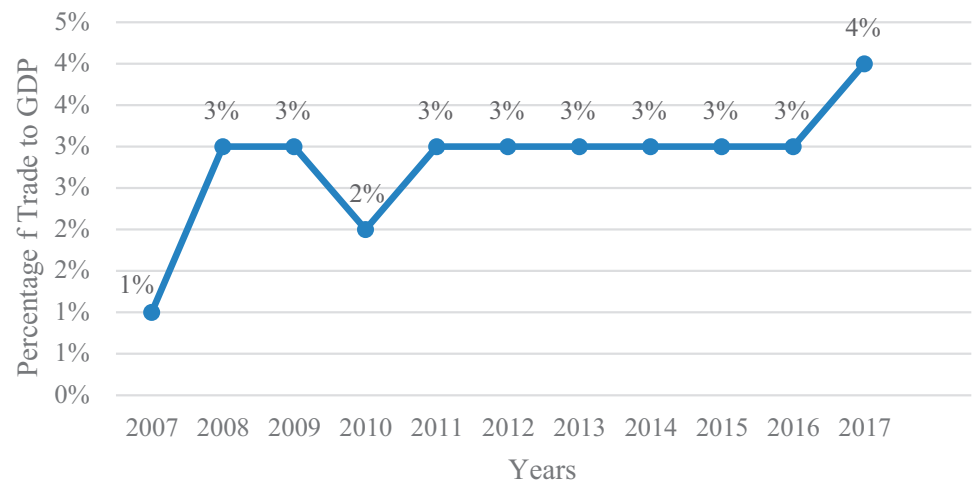

Source(s): UN Comtrade (December 2020). Data was compiled and processed by the author
China drive toward Africa Egypt as case study

143

Figure 1.

Egypt-China trade-toGDP-ratio from 2007 until 2017

Beside the imbalance of trade, another obstacle is observed in Sino-Egypt trade relations that is the ill diversification of products either in imports or in exports as shown in the figures. Such obstacles are being addressed by China, for example through hosting the International Import Expo in Shanghai to gather all manufacturers and trading firms around the world into one big event with special focus on SMEs. Figures 2 and 3 present the type of exports and imports between Egypt and China.

As shown in Figure 2, Egypt is importing from China machinery and transport equipment that constitutes $42 \%$ of overall imports followed by manufactured goods $33 \%$, given the fact

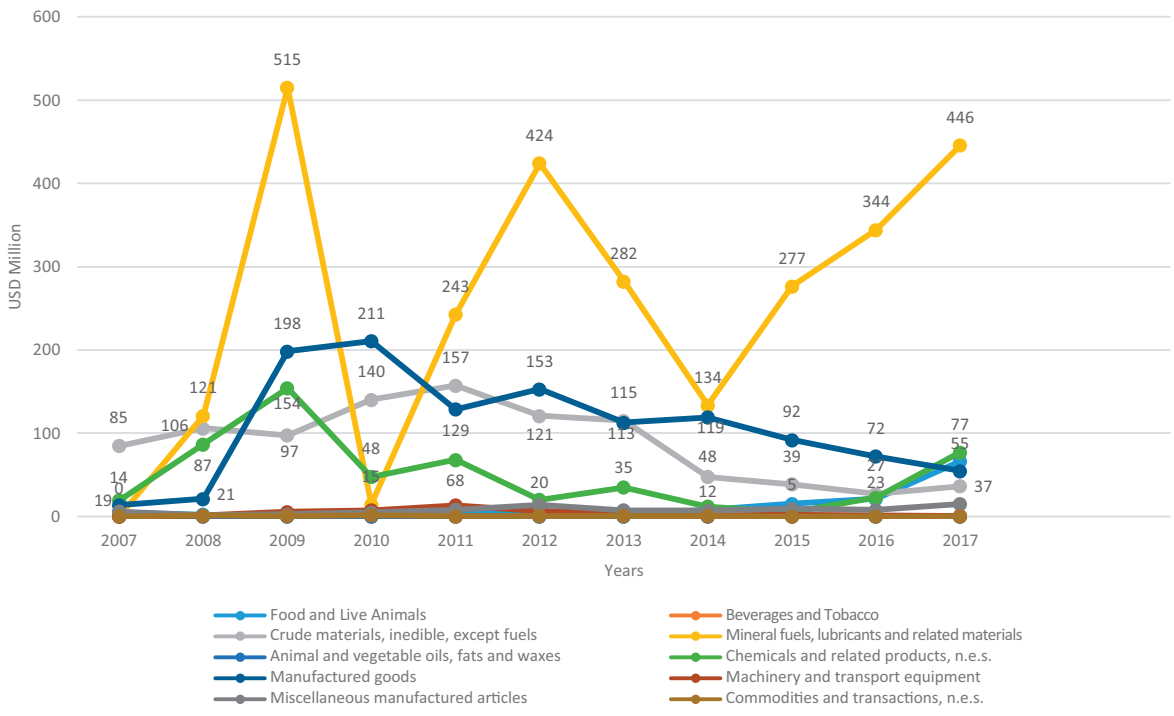

Source(s): UN Comtrade (September 2020). Data were compiled and summarized by the author

Figure 2.

Egypt exports to China in USD million (2007-2017) 
REPS

7,2

144

Figure 3.

Egypt imports from China in USD million (2007-2017)
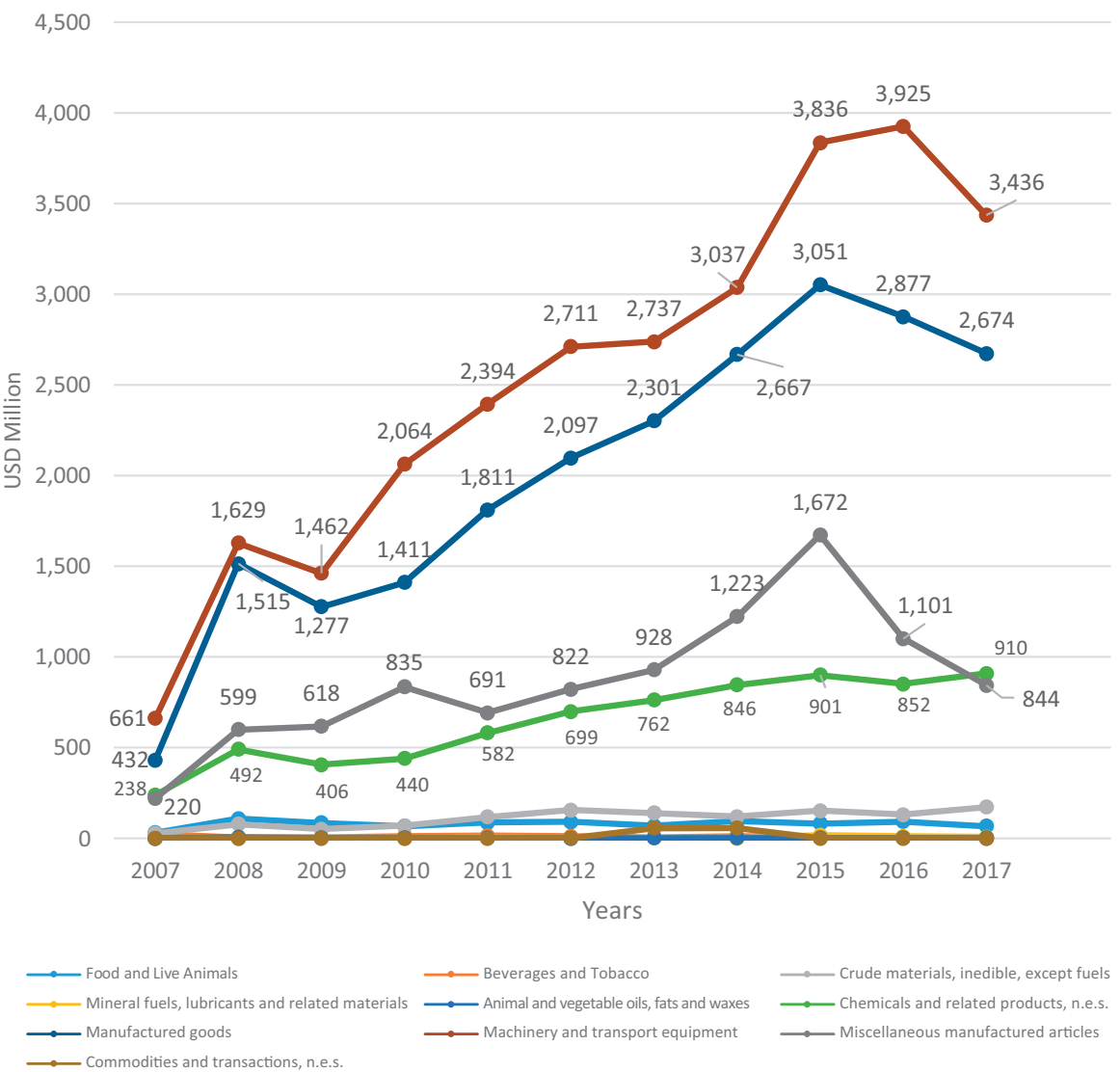

Crude materials, inedible, except fuels

$\longrightarrow$ Chemicals and related products, n.e.s. Miscellaneous manufactured articles

Source(s): UN Comtrade (September 2020). Data were compiled and summarized by the author

of the relatively low prices provided by China compared to EU or Western economies in general. While the exports side, as shown in Figure 3, is even less diversified as the lion share of exports to China is in minerals fuels and related materials constituting $64 \%$, which heavily started since 2008 replacing and surpassing crude materials exports exceeding US\$ 445 million in 2017 compared to US\$ 36 million for crude materials in the same year.

Pieces of evidence on neo-colonialism or mutual beneficial relationship

The increasing trade relations between the two countries is perceived by neo-liberalists advocates as an economic interdependence and source of power for partner countries regardless the imbalance of trade that exist. It is a sign of interdependence because it coincides with the need of developing countries to such cheap machinery and technology provided by China. On the other side, Egypt abundance of marble and granite has found huge market in China. In 2018 China imported $65.8 \%$ of Egypt's exports of marble and granite. Such gradual increase of interdependence over the years, though insignificant if compared to the balance of trade between Egypt and EU, but may at some point in the future bypass EU 
volume of trade with Egypt as happened in 2012 when China bypassed USA, Egypt's top trading partner, in exports.

If the imbalance continued without any corrective actions from Egypt, trade balance will worsen and get further distorted. In addition, China has a potentially huge market for Egyptian products, which is a good opportunity for Egypt to consider performing extra measures in diversifying the classical destinations of its products beyond EU and USA markets.

Such pattern of trade is relatively consistent with the rest of North African states as well sub-Saharan sphere, where China's export of phosphates has an important portion of trade with Morocco and fertilizers with Tunisia and large energy supply is exported to China from Libya and Algeria. While the largest portion of the Chinese exports to Northern countries of Africa are occupied mainly by manufactured goods and textiles. Moreover, beside Egypt, Algeria has a Comprehensive Strategic Partnership with China since 2014 and Morocco has a Strategic Partnership since 2016.

In order to benefit from such relations, the Chinese manufacturers open new factories in North Africa and sell to EU based on preferential trade agreements signed between EU and northern countries of Africa. Competition in EU markets between locally manufactured light industries like textiles in Africa with those made in China was in favor of the Chinese products to the extent that EU introduced a quota system that restrict importing Chinese garments to EU in 2005 to give opportunity to Tunisian and Moroccan production lines to develop their techniques. This was not the case when the system ended in 2007 where the Tunisian exports fell by $22 \%$ because of competition from Chinese exports to EU (Liste, 2012).

The pattern of trade between Egypt and China may not be complex as the trade pattern between Egypt and EU, but more solid relations are on the horizon especially after the BRI initiative of China that encourages countries to be more involved in a complex interdependence relationship.

To sum up, the imbalanced trade relations between Egypt and China that are relatively in favor of China might be perceived from the scope of dependency advocates as an indication of a neo-colonial pattern of relationship rather than mutual benefit, but the mutual respect on the official and non-official levels in addition to the tangible economic benefits emphasize the mutual-benefit side. It is worth noting that in 2018 China-Africa trade volume amounted to US\$204.2 billion, which indicates the large proportion Chinese trade is occupying in Africa's trade volume.

\section{Development aid between China and Egypt}

ODA definition of development aid, which the present paper adopted in Egypt-EU section above, cannot be partly relied upon in this section due to many reasons. First, China is not a member of the Organization for Economic Co-operation and Development-Development Assistance Committee ("OECD-DAC") and does not report aid figures to DAC and most of figures published in research papers are based on estimates grasped from various sources. Second, are calculated differently from the standard categories adhered to by OECD-DAC, therefore are not comparable. Third, China, though a growing large donor, is listed on OECD data as a development aid recipient, which brings us to the issue raised in the review of literature part that China, though a raising power, yet it is not a fully-fledged hegemon, which might have some positive implications for China and gives it the opportunity to develop without carrying some of the burden of global affairs. Fourth, definition of aid within Chinese circles differs from that adopted by OECD members making crosscut comparisons a challenging task. Fifth, the main official data emanates from white papers that describe overall disbursement without giving details on how much money is directed to what country and its aim. 
REPS

7,2

146

In pursuing coordination on aspects of interest with African counterparts, China was able to deal bilaterally with African countries without resorting to the guiding principles of aid, including human rights conditions and political interference, that were adopted and developed by western donors over years. China developed its own principles, opposing power politics that dominated international relations for centuries, that emanates from China's five principles of peaceful coexistence developed in fifties.

China started to extend aid beyond socialist countries in 1956 following the Afro-Asian Conference in Bandung, Indonesia in 1955 that paved the way for non-aligned movement few years later and targeted African countries. In 1964, during a visit to Accra, Ghana, then Chinese premier Zhou Enlai unveiled a formalized set of ideas China named the Eight Principles for Economic Aid and Technical Assistance to Other Countries. The most prominent features in the eight principles are: asserting equality and mutual benefit; respecting sovereignty and attaching no political conditions or interfering in internal affairs of recipient countries; assisting countries to self-reliance and achieve independent economic development. In mid-1990s, China coordinated external aid through internal coordination between state organs, including Ministry of Commerce, Ministry of Foreign Affairs, State Administration of Foreign Exchange, Ministry of Education, and Ministry of Agriculture; above all China established two banks in 1994, Export-Import Bank of China and China Development Bank, which subsequently became the pillars of China's foreign aid and development finance (Cheng, 2019). Involving state organs, especially the Ministry of Commerce, in managing development assistant raised critiques against China and accusations of neocolonialism practices through debt trap diplomacy (Cheng, 2019).

The Chinese assistance to Africa started to attract international attention after the country invited African counterparts into its first Forum on China-Africa Cooperation ("FOCAC") in 2000, which finds its way among well-recognized multilateral arenas of cooperation between China and African countries. FOCAC is considered by some scholars as a vital part of China efforts to operate under the umbrella of a South-South cooperation framework (Wu, 2012).

The first official document, white paper, on foreign aid released by China in 2011 where it introduced itself as a developing country and describing its foreign aid as "a model with its own characteristics" (China's Foreign Aid, 2011). In the paper, China summarized the development it pursues in aid strategies and officially stated the main features of foreign aid that evolved features from the five principles of coexistence and the above-mentioned eight principles.

China divided the types of foreign aid into three main types: grants, interest-free loans and concessional loans, which can be qualify in part within the framework of ODA definition (Wu, 2012). The first two comes from the State while the third one is made through Export-Import Bank of China that provides subsidized loans. Grants are provided to establish schools, watersupply projects and other small and medium projects. Interest-free loans are used to cover the establishment of public facilities where such projects enjoy tenure of 20 years. Concessional loans cover medium- and large-sized projects in infrastructure, energy and resources and communications ... etc. The grant element of $25 \%$ in development aid provided by OECD donors is not necessarily followed by China as a large proportion of its financial assistance comes within the form of export credit lines and market or close-to-market rate loans, which makes it hard, in the absence of accurate data, to believe that China has pure intentions toward African development (Dreher et al., 2017). Such main types are performed through many forms: the establishment of complete projects starting from study and ends with trial production before delivery; the provision of experts; the provision of training for personnel and individual exchanges; the provision of medical services through teams and devices; debt relief that was made on high profile occasions such as FOCAC convened in 2000, 2006, 2009 and UN HighLevel Meeting on the Millennium Development Goals in 2008 and 2010 where 35 African countries were relieved from debts by the end of 2009 (China's Foreign Aid, 2011). 
The second white paper on China's Foreign Aid (2014) identified a remarkable increase in financial resources given to developing countries to reach a total of 89.34 billion Yuan for foreign assistance between 2010 and 2012 compared to 256.29 by the end of 2009 since it started to provide such aid. In the second paper it is noticed that China has increased its concentration on certain projects such as agriculture, education, medical and health services and continued the establishment of prestige projects and trade-related infrastructure projects (China's Foreign Aid, 2014). In China's second Africa policy paper published in 2015, it assures the principles of non-interference and attaching no political conditions or imposing demands on African countries in return for assistance from China. Beside Export-Import Bank of China providing loans, in the second policy paper of 2015 China presented its multi financing platforms such as: The China-Africa Development Fund (under China Development Bank), the Africa Growing Together Fund, China-Africa Industrial Cooperation Fund (under Export-Import Bank of China), and the BRICS' New Development Bank. It is noticed in these policy papers that China promotes its image as a partner not a donor and its aid portfolio is oversaw by complicated network of ministries and policy banks instead of a single aid agency.

Egypt was among the first non-communist countries in Africa to receive aid from China upon Bandung Conference in 1955. In 1956, China though a bit reluctant to support the Egyptian position regarding the nationalization of Suez Canal as it took almost three weeks to announce official support from Beijing, but responded quickly in condemning the aggression and supporting Egypt's position vis-à-vis the aggression from France, England and Israel. China paid Egypt 20 million Swiss francs upon the freezing of Egypt's deposits; donated 170.000 Swiss francs from the Chinese Red Cross; China continued to buy cotton and provided considerable quantities of principal goods ahead of schedule; and established Department of West Asia and Africa in the Ministry of Foreign Affairs in order to adapt to such situation of aggression and its desire to deepen relations with Egypt and countries in the Middle East (Shichor, 2008).

Since then China started to support various Sub-Saharan countries the years to follow such as the huge railway project that connected between Zambia and Tanzania, named "TanZam" in 1976 where the cost exceeded one billion RMB (Gountin, 2006). In this early period China's objectives behind aid were on gaining political recognition vis-à-vis Taiwan and spreading its ideology vis-à-vis the Soviet Union; and benefiting recipient countries because it offers aid in forms of interest-free loans or as grants (Nowak, 2015). Later on China's objectives from the provision of aid changed from political ones into achieving economic prosperity of its economy and supporting the economy of the recipient countries as it ties foreign aid with trade and investments, as well based on its own characteristics and models of assistance. Such Chinese model of assistance was realized in Egypt as China injected almost US $\$ 20$ billion into the Egyptian economy in the form of loans, investments and development projects; such funds were mainly in infrastructure, energy and telecommunications sectors, dedicated to projects such as the development of the Suez Canal Economic Zone, a light rail transit system to connect cities outside of Cairo to the new administrative capital, and solar power stations adjacent to Aswan (TIMEP, 2019). It is worth nothing that Chinese development assistance is usually given in kind for example, the officially exchanged note between the two countries over the provision of 700 vehicles to Egypt in 2011. While the financial assistance is usually given to fund contracts that are implemented by Chinese companies such as the towers in the new administrative capital of Egypt (Berthelemy, 2011).

When it comes to reporting of constant figures across years, China's government considers its international development finance program to be a "state secret" (Bräutigam, 2009, p. 2). It does not disclose detailed or comprehensive data about development projects conducted abroad that it finances, nor does it publish a bilateral breakdown of its international development finance activities (Dreher et al., 2017).
China drive toward Africa Egypt as case study 
REPS

7,2

148
Pieces of evidence on neo-colonialism or mutual beneficial relationship

A growing concern over development aid provided by China to African countries lies mainly in the unpublished actual bilateral aid numbers. Concessional loan disbursements or loan repayments that are not published raise concerns of putting developing countries in danger of slipping into major debt crisis. IMF warned recently that Africa is heading towards a new debt crisis and WB classifies 18 states in Africa as at high risk of debt distress as debt-to-GDP ratios transcends $50 \%$, where approximately $20 \%$ of external debt of governments in Africa is owed to China (BBC News, 2018). In addition, there are no official data on Chinese loans exist and thus all published figures are estimates and guesses, given the fact that Beijing is not a member of the OECD and it does not take part in the OECD's Creditor Reporting System. In addition, the Chinese state banks seldom release information concerning detailed financing contracts while recipients of such loans invariably fail to completely divulge the information of the finances they are obtaining (Taylor and Zajontz, 2020).

Moreover, the imposition of the concept of One China as a condition of China's cooperation with countries is a type of coercion and neo-colonial practice toward developing countries in Africa. Such attitudes create an area of influence manipulating the ideal aim of development aid, which coincides with the point of view of dependency advocates. In addition, allegations of neo-colonialism are enhanced further because Chinese foreign assistance today is provided mostly on a state-to-state basis, concentrated in physical infrastructure construction and aimed at further access to natural resources and overseas markets.

On the other hand, China's infrastructure provision using concessional loans in the African continent is reflecting its own believe of the unique development bath that each country should follow. By building infrastructure projects in Africa, like roads, dams and telecommunications equipment, China benefits other economic sectors such as trade and industry. Such believe is enhanced through China's adoption of Five Principles of Peaceful Coexistence -which are: mutual respect for each other's territorial integrity and sovereignty, mutual non-aggression, non-interference in each other's internal affairs, equality and mutual benefit and peaceful co-existence- that is considered a cornerstone on its development assistance provided to countries in Africa. China uses these principles to overcome the rhetoric against the claims over neo-colonial practices. In addition to the well-established China's aid programs such as medical teams, technical assistance, and peacekeeping forces sent to countries of need in Africa that China are conducted under the mandate of international organizations such as UN.

In reference to the allegations of China's seizer of national assets in return for repayment of debts, the case of Hanbantota port in Sri Lanka remains the only cited case of China's "predatory lending". A study by the Centre for Global Development found that the Belt and Road Initiative has not contributed to debt-distress in most of the countries involved in the initiative. Eight out of the sixty eight BRI-involved states were found to be at risk of debtdistress from BRI borrowing. The country of Djibouti is one of these eight at risk, but no evidence of asset seizure or ownership transfer resulting from countries' debt-situation was cited to the author's knowledge, and the Djiboutian government owns the constructed infrastructure (Chen, 2020).

Even the One China policy maintained by China that is translated by neo-colonial advocates as a condition on African counterparts is considered a core principal of China foreign policy that is even exerted with United States, for example the tension occurred when the White House granted visa to the Taiwanese president Lee Teng-Hui in 1995 to visit United States for a non-official purpose.

To conclude, it is early to claim that China is a neo-colonizer, either in the case of Egypt or Africa in general as evidences of this is more of media rhetoric than actual incidents. 


\section{Conclusion}

The research in hand tried to add to the literature of the constant debate on China's scramble toward the African continent. The main argument was to investigate whether China's approach toward Africa is a sort of neo-colonialism or is based on a mutual benefit between the African countries and China. Egypt was selected as a case study to elaborate such relationship and the timeframe of the research is from 2007 until 2017. The answer to the main question was made through analyzing the relationship between Egypt and China relying on two items: Trade and Development Aid. The study encompasses two sub-questions. The first sub-question investigates the relevant theory that could describe the relationship between China and Africa, Egypt in specific. The second sub-question investigates the evidences on neo-colonialism or evidences on mutual beneficial relationship. In order to answer the first sub-question, Interdependence theory from the international political economy was selected to study the identified pillars of analysis, Trade and Development Aid and to measure the extent of interdependence between the two countries.

In regards to data analysis of the trade aspect, from 2007 until 2017 the trade volume increases between Egypt and China and is enhanced through the pattern of no strings attached between the governments of both countries, which indicates a mutual respect and understanding on the political dimension. The proportion of China volume of trade-to-GDP for Egypt's economy is of great indication to Egypt's openness to diversified international actors rather than the classic actors such as EU or US.

In regard to Development Aid data analysis, China's model of development aid and due to its provision of ODA outside the DAC paradigm that undermines the analysis. Nevertheless, allegations of neo-colonialism minimize the role of countries' will and the institutional framework governing many aid provision schemes with developing countries. The mutual consent between Egypt and China in terms of trade and development aid enhances the relationship and indicates a complex interdependence between the two countries in the future that would transcend to more political synergy, which was emphasized in recent years through the synergy of Egypt sustainable development plan "Vision 2030" made with China "Belt and Road" initiative.

To wrap up, in order to make the relationship between Egypt and China more balanced, on the Egyptian side, Egypt needs to focus more on improving its industrial goods to be able to access and compete in the Chinese huge market and start develop the technological base required for the production. Furthermore, Egypt can provide advantages to the Chinese manufacturers when they establish their business in Egypt and benefit from the bilateral and multilateral trade agreements signed between Egypt and countries in Africa, Middle East, USA and the European Union. Such agreements benefits manufacturers commencing business in Egypt, as they can obtain raw materials, initial and intermediate goods from these countries without customs, or with limited customs. On the Chinese side, China has to give more privileges to the Egyptian products to access China markets. The synergy between Egypt "Vision 2030" and China "Belt and Road" initiative has to be applied effectively to stress on the interdependent and win-win relationship.

\section{References}

Akwiri, J. (2015), Kenya Announces Plan to Buy Land for Standard Gange Railway, Reuters.

BBC News (2018), Reality Check: Is China burdening Africa with Debt?, November 5, BBC News (accessed 06 October 2020).

Bräutigam, D. (2009), The Dragon's Gift: the Real Story of China in Africa, Oxford University Press, Oxford.
China drive toward Africa Egypt as case study 
REPS

7,2

Berthelemy, J.-C. (2011), China's Engagement and Aid Effectiveness, African Development Bank, Tunisia.

Chen, J. (2018), "Strategic synergy between Egypt 'vision 2030' and China's 'Belt and road' initiative”, Outlines of Global Transformations: Politics, Economics, Law, Vol. 11 No. 5, pp. 219-235.

Chen, Y. (2020), Chinese Debt and the Myth of the Debt-Trap in Africa, Italian Institute for International Political Studies.

Cheng, C. (2019), The Logic Behind China's Foreign Aid Agency, Carneigie Endowment for International Peace, Washington, DC.

China's Foreign Aid (2011), Information Office of the State Council of the People's Republic of China, The State Council, Beijing (accessed 25 June 2020).

China's Foreign Aid (2014), Information Office of the State Council of the People's Republic of China, The State Council, Beijing (accessed 26 June 2020).

Chinese Premier Wen Jiabao (2006), Transcript of Premier Wen's Press Conference in Cairo, China Daily, Beijing.

Cooperation between Egypt and China in Brief (2004), Economic and Commercial Office of the Embassy of the People's Republic of China in the Arab Republic of Egypt, Ministry of Commerce, Beijing.

del Rosío Barajas-Escamilla, M., Kia, A. and Sotomayor, M. (2016), "Concepts and measurements of economic interdependence: the case of the United States and Mexico", Germany: Global Economy Journal, Vol. 16 No. 1, pp. 63-90.

Dreher, A., Fuchs, A., Parks, B., Strange, A.M. and Tierney, M.J. (2017), Aid, China, and Growth: Evidence from a New Global, W\&M's Global Research Institute, Virginia.

Dynamic, B.M. (2019), “China's power in Africa: rhetoric and reality”, in Golley, J., Jaivin, L., Farrelly, P.J. and Strange, S. (Eds), Power. Essa., ANU Press, Canberra.

Gadallah, Y.M. (2016), "6 an analysis of the evolution of Sino-Egyptian economic relations", in Horesh, N. (Ed.), Toward Well-Oiled Relations?: China's Presence in the Middle East Following the Arab Spring, Palgrave Macmillan, Houndmills, Basingstoke, Hampshire, pp. 94-114.

Gountin, V. (2006), China's Assistance to Africa, a Stone Bridge of Sino-African Relations, Renmin University of China, Center on China's Transnational Relations (accessed 27 June 2020).

Grimm, S. and Hackenesch, C. (2017), "China in Africa: what challenges for a reforming European Union development policy? Illustrations from country cases", Development Policy Review, Wiley-Blackwell, Vol. 35 No. 4, pp. 549-566.

Hatab, A.R., Shoumann, N.A. and Xuexi, H. (2012), "Exploring Egypt-China bilateral trade: dynamics and prospects", Journal of Economic Studies, Vol. 39 No. 3, pp. 314-326, doi: 10.1108/ 01443581211245892.

Keohane, R.O. and Nye, J.S. (2012), Power and Interdependence, 4th ed., Longman, Boston, MA.

Lanteigne, M. (2009), "China in the World economy", Chinese Foreign Policy: An Introduction, Routledge, Abingdon, pp. 39-55 (accessed 1 June 2020).

Liste, J. (2012), Chinese Investments and Employment Creation in Algeria, ECDPM, Maastricht.

Martin, G. (1985), "The historical, economic, and political bases of France's African policy”, The Journal of Modern African Studies, Vol. 23 No. 2, pp. 189-208.

Manero, E. (2017), “China's investment in Africa: the new colonialism?”, Harvard Political Review.

McGreal, C. (2007), "Hu Jintao starts Africa tour with loans promise", The Guardian.

Msimango, N. (2016), "Chinas changing foreign policy and resource diplomacy towards Africa: the role of china in the socio-economic development of Nigeria", (Unpublished Doctoral Dissertation), University of South Africa.

Nowak, W. (2015), “China's development aid strategies”, Chinese Business Review, Vol. 14 No. 4, doi: 10.17265/1537-1506/2015.04.004. 
Ogunsanwo, A. (1974), China's Policy in Africa 1958 - 71, Cambridge Univ. Pr, London.

Shichor, Y. (2008), "Sino-Arab peaceful coexistence", The Middle East in China's Foreign Policy, 19491977, Cambridge Univ Press, pp. 48-51.

Stevenson, T. (2006), Chinese Moves Spawn a New Order, The Telegraph.

Sun, Y. (2014), “Africa in China's Foreign Policy”, in John, L. (Ed.), Thornton China Center and Africa Growth Initiative, The Brookings Institution, Washington, DC.

Tan, E., Kim, S.J. and Kim, G. (2015), "Norman Angell and the logic of economic interdependence revisited: 1914", Asia Europe Journal, Vol. 13 No. 4, pp. 479-500, doi: 10.1007/s10308-015-0428-8.

Taylor, I. (2006), "China's oil diplomacy in Africa”, International Affairs, Oxford University Press, Vol. 82 No. 5, pp. 937-959.

Taylor, I. and Zajontz, T. (2020), "In a fix: Africa's place in the Belt and Road Initiative and the reproduction of dependency", South African Journal of International Affairs, Vol. 27 No. 3, pp. 277-295, doi: 10.1080/10220461.2020.1830165.

TIMEP Brief (2019), China's Role in Egypt's Economy, The Tahrir Institute for Middle East Policy, Washington, DC.

Wu, C.-H. (2012), "Beyond European conditionality and Chinese non-interference: articulating EU -China -Africa trilateral relations", in WoutersJ., de Wilde, T., Defraigne, P. and Defraigne, J.-C. (Eds), China, The European Union and Global Governance, Edward Elgar Publishing, ISBN: 9781781004265, pp. 106-124.

Zambelis, C. (2013), Egypt Turns Quietly to Asia, The Middle East Institute, Washington, DC.

Zhongping, F. and Jing, H. (2014), China's Strategic Partnership Diplomacy: Engaging with a Changing World, FRIDE, Madrid.

Zongze, R. (2008), "China-EU-US relations: shaping a constructive future", in Shambaugh, D., Sandschneider, E. and Hong, Z. (Eds), China-Europe Relations: Perceptions, Policies and Prospects, 1st ed., Routledge, Oxfordshire, pp. 287-300.

Zweig, D. and Jianhai, B. (2005), “China's global hunt for energy”, Foreign Affairs, Vol. 84, doi: 10. 2307/20031703.

\section{Further reading}

Bräutigam, D. and Tang, X. (2014), “Going global in groups': structural transformation and China's special economic zones overseas", World Development, Vol. 63, pp. 78-91, doi: 10.1016/j. worlddev.2013.10.010.

Dynamic, B.M. (2016), “China's power in Africa: rhetoric and reality”, Power. Essay, Polity.

Kalu, N.E. (2012), "Understanding Africas China policy: a test of dependency theory and a study of African motivations in increasing engagement with China", (Unpublished Doctoral Dissertation).

Ministry of Foreign Affairs of the People's Republic of China (2013), China and Egypt, Ministry of Foreign Affairs, the People's Republic of China, Beijing.

Team, R. (2018), Reality Check: Is China Burdening Africa with Debt?, BBC, (accessed 6 October 2020).

The Biggest China-aid Project to Egypt in 2011 (2011), Economic and Commercial Office of the Embassy of the People's Republic of China in the Arab Republic of Egypt, Chinese Vehicles Project Officially Kick-started, Ministry of Commerce, Beijing.

Santos, T.D. (1970), "The structure of dependence", The American Economic Review, American Economic Association, Pittsburgh, Vol. 60 No. 2, pp. 231-236.

Wenyuan, M.A. and Jun, Z.H.A.O. (2020), China-Egypt Financial Cooperation: Developments and Problems, ResearchGate, Berlin. 
REPS

7,2

\section{Corresponding author}

Alyaa Wagdy el-Shafei can be contacted at: a.elshafei@gafinet.org.eg, alya_wagdy@yahoo.com

\section{2}

For instructions on how to order reprints of this article, please visit our website: www.emeraldgrouppublishing.com/licensing/reprints.htm Or contact us for further details: permissions@emeraldinsight.com 